\title{
Towards a new research model in legal translation: future perspectives in the era of asymmetry ${ }^{1}$
}

\section{Maria Carmen África Vidal Claramonte}

University of Salamanca, Spain

africa@usal.es

The global society we live in leads to clashes and asymmetry between cultures. In this context, translation and legal studies play a fundamental but also very sensitive role. The old concepts of the Enlightenment, Reason, universalism, objectivity or the universal no longer serve any purpose either in the field of translation or in that of law. This paper proposes a research model based on post-structuralist concepts such as those of "differend", "representation" or "aporia". This model can help us conceive new ways of translating legal texts in the future that are more in line with the asymmetrical problems of our contemporary society.

\section{Taking up positions: new avenues in legal studies}

In legal theory, the modern approach was traditionally characterised by a belief in the power of Reason and the inherent uniqueness and coherency of stable individuals and a belief in the principles of law as being objective, absolute, eternal and universal. Modern philosophy, from Locke and Kant to Descartes, sought to provide universal criteria for discovering truth and universal moral principles through language, which was considered to be neutral and referring to a single "correct" meaning. Thus, law and legal texts have traditionally been conceptualised as repositories of Truth, as universal, neutral and ahistorical.

However, for a few decades now, some legal studies scholars have criticised the modern approach because they have realised that it does not correspond to the typical asymmetries of a multicultural, global and hybrid society. Influenced by the so-called "crisis of representation" (Arrojo, 1998, 1999, 2001a, 2001b; Belsey, 1980/1985 ; Benjamin, 1989; Foucault, 1966, 1970) that has become established in the human and social sciences since the 20th century, new legal theories are questioning the modern view of law and its principles, and are instead re-discovering laws as texts or, ultimately, as language. This is a view to which translation, too, has a great deal to contribute.

The so-called Critical Legal Studies and their corollaries, Feminist Jurisprudence or Critical Race Theory, were extremely interesting and controversial branches of law that emerged in the United States in the late 
1960s. They attempted to challenge legal orthodoxies and the very idea of justice by emphasising the political ideologies that lie behind legal reasoning. After all, the inability of law to recognise diversity and thus to compensate for the structural inequalities dividing human beings had become evident. Contemporary legal theorists such as Stanley Fish, Peter Goodrich, J. M. Balkin, Richard Delgado, H. L. A. Hart, Ronald Dworkin, Gillian Rose, Drucilla Cornell, Duncan Kennedy and Allan Hutchinson claim that legal studies must be brought up to date and take into account the fact that they should be at the service of a society which has changed greatly in only a few years.

Whereas the Enlightenment modernism of Descartes or Kant saw reason as a universal faculty, thinkers such as Foucault, Horkheimer and Adorno, Lyotard and Rorty have taught us about the limits and dangers of reason.They argue for a socially constructed reason always situated within existing practices and discourses and, therefore, biased in favour of existing power relations. In this same line of thinking, another key philosophical concept, the self, has been deconstructed: after poststructuralist philosophy, there no longer is a unified core self, but there are decentred individuals who are the product of language and discourse and who no longer believe in a fixed Truth which mirrors the correspondence between language and reality. Even concepts such as "law" and "justice" are beginning to be distinguished from each other according to authors such as Michel Foucault, Jacques Derrida and JeanFrançois Lyotard: for Foucault, for example, a culture's fundamental codes (those which govern its language, its perceptive ideas, its values, its hierarchies) establish beforehand the empirical orders in which we recognise ourselves, naturalising them for us. In the name of this order, other representations of the world become invalid. This is especially important when the representations being dealt with are related to concepts such as justice, truth, race, gender and ideology.

Foucault discusses the idea of justice as an idea which has been invented and put into practice in different societies as an instrument of political and economic power. According to Foucault (1971/1994), power should be considered to be present not only in state or legal systems, but also in the education system, in psychiatric institutions, in the culture industry, etc. The latter are even more dangerous because they are presented as neutral systems without ideological interests.

Derrida (1989/1992), on the other hand, understands that law is not justice:

Law is the element of calculation, and it is just that there be law, but justice is incalculable, it requires us to calculate the incalculable; and aporetic experiences are the experiences, as improbable as they are necessary, of justice, that is to say of moments in which the decision between just and unjust is never insured by a rule. (p. 16) 
Law is a system of determinate rules, an act of interpretive violence, a construct, whereas justice reveals a responsibility, a duty to the other, which turns out to be an aporia (Derrida, 1989/1992, p. 3; see also Derrida, 1981). Contrary to the vision of laws as something truthful, unambiguous and thus unmovable, Derrida and others see them as simply texts (Heller, 1992, p. 351; Hillis Miller, 1992, p. 306) in which meaning is never fully present, and the sign is deferred presence, never enclosed within rigid boundaries but disseminated and open (Derrida, 1972/1982, p. 9).

Lyotard (1979/1984, 1979/1985, 1983/1988), for his part, has much to say about the problem of reaching justice in a multicultural society deeply divided by questions of race, religion, class or gender. In his view, the individual is created by small narratives which, unlike grand narratives, do not seek hegemony over other narratives. Small narratives are Wittgensteinian "language games" that create the individual. No single language game is more valid than any other, which means that any hope of a single and hegemonic principle of justice (which would silence minorities) has to be abandoned in favour of a series of microjustices tied to a localised small narrative. For this reason, Lyotard introduces the term "differend", which implies a conflict between two systems of justice. He exemplifies the "differend" in asymmetrical situations, including the situations of wage labourers and indigenous peoples.

These new philosophical views on old concepts emphasise the value of difference and heterogeneity, the multiplicity of interpretations and the openness of texts as elements opening up avenues for dialogue. I consider the various components of the model I would like to propose in this paper (representation, differend, reality as a construction of language, unstable meaning, and others) to be very important and believe they should be applied to the translation of legal texts, because the normative model is proving to be insufficient in today's hybrid, global, asymmetrical world where different cultures are forced to have coexisting identities which are constantly changing and in conflict. Authors such as Rosemary Arrojo (1994, 1998, 1999, 2001a, 2001b, 2001-2002), Kathleen Davies (2001) and Jacques Derrida (1996/1998, 2000, 2001) have applied many of these concepts to translation, since they have been aware of the importance of ideas such as différance, crisis or representation in contemporary society. In this essay the reader will discover how the aforementioned post-structuralist concepts reflect the multiple and changing realities that we translators inhabit; asymmetrical realities which have been built through discursive representations characterised by the differend. Contemporary translators inhabit multiple realities and cannot limit themselves to universal and uniform translating formulae. If they did, all respect for diversity would be lost, particularly in places where the legal translator is so necessary in contemporary society: police stations, courts of law, NGOs and international organisations. Under the flag of globalisation, all of these places conceal 
huge differences between globalised and globalising (Appiah, 2006; Bauman, 1999; Beck, 2006; Bielsa, 2010; Bielsa \& Hughes, 2009; Castells, 2009; Cronin, 2003; Delanty, 2009).

These new approaches to law and justice encourage us to interrogate so-called performative legal discourses - those producing rights and norms - and to call into question the institutions that act as control mechanisms of discourse, restrain the proliferation of meaning, and repress its multiple potentialities in favour of certain institutionalised options in accordance with the prevailing orthodoxy or the established doctrine - "doctrine" being a term widely used in the legal domain (Vidal \& Martín, 2003, p. 142).

\section{Towards a new research model in legal translation in the era of asymmetry}

\subsection{Beyond stable meaning}

In today's world, in which asymmetries between identities are reactivated by tensions between the local and the global, post-structuralist thought can help to overcome Western thinking, which has long been dominated by strongly biased perspectives and which can be detected, for example, in many metaphors used by legal experts and translators in the legal language employed in international fora such as the European Parliament. This has been demonstrated by various studies (Beaton, 2007; Koskinen, 2000a, 2000b, 2008), which reveal how the language demanded of translators and interpreters in many public institutions reinforces dominating identities and ideologies and minimises the traffic of heteroglossic voices and identities (Beaton, 2010; Tosi, 2003). In my opinion, if the current asymmetry is to be overcome, international institutions should try to include these new concepts and proposals in legal translation, an idea already put forward by the authors I have just mentioned, among others.

Traditional views on language force it to contain and safeguard meaning, and translation - an interpretative act - is accordingly forced to refuse to interpret. That is why Holly Mikkelson (2000), one of the most well-known authors in this field, wrote a few years ago that "as the court interpreter, you are a language expert, and you are not necessarily qualified about cultural practices" (p. 60). Law is one of the cultural fields in which terms are more system-bound (Harvey, 2002, pp. 179180), because legal translators and interpreters are regarded as mere linguistic messengers: their institutional role, particularly in the context of the European Union, as criticised by some authors (Koskinen, 2008; Martín Ruano, 2012), is that of mere text processors. From this point of view, the translator's main task in translating legal documents still is, in 
many institutional domains, to translate a text as precisely, faithfully, accurately and neutrally as possible, trying to find linguistic equivalents. These ideas, still to a large extent prevalent today in institutional legal translations, are based on codes of ethics that literally oblige interpreters and translators to observe impartiality in all professional contracts and take all reasonable care to be accurate. In the field of legal translation, and as an example of what we have referred to above, the norm of hegemonic linguistic concordance is recurrent in the context of the European institutions, as shown in Strandvik's study (2002, p. 461; see also Martín Ruano 2012 and Nóbrega 2010).

For a few decades now, however, many authors in the field of legal translation have been questioning the trustworthiness of the codes of practice issued by translators' unions, translators' charters, ISO 9000 and other quality standards (Chesterman, 1997, p. 189; Koskinen, 2000a, p. 82), which all keep up the illusion of unmediated communication (Koskinen, 2000a, p. 82). The new trends in legal studies make us realise that in our post-foundational, multicultural and asymmetrical societies the concepts of Truth, Objectivity, Neutrality and thus Fidelity are being questioned. Furthermore, where legal translators face challenges never encountered before, such as those suggested in very different contexts by the scholars previously mentioned and many others (see, for instance, Brown, 1995, and Cooke, 1995), the theoretical basis informing those legal translation practices, still anchored in once supreme absolute values, needs to be revisited.

This trend in changing the way we translate legal texts has come about because the new theories on translation, which started at almost the same time as the new views on law mentioned above, leave behind the chimera of the detachment and non-intervention of the translator in the process. It has become necessary to introduce changes in legal translation because translating today implies giving voice and recognition, projecting visions of certain identities and reshaping existing visions in order to avoid the alienation, negation and exclusion of identities which are constantly renegotiating their relations in a global and cosmopolitan, hybrid and unsettled world, at a time when the asymmetries between cultures are so significant and the risks of misunderstandings in legal and institutional contexts may have important ethical consequences (Martín Ruano, 2012, p. 65). Thus, a lack of attention to pragmatic aspects of language may result in the skewing of a speaker's intended meaning: a translator can make the tone of a witness's testimony or an attorney's questions harsher and more antagonistic than it was when originally uttered, or softer and more cooperative, and for the most part these changes are made silently. However, we should be aware of the impact that these alterations can have on judges and jurors (Berk-Seligson, 1990/2002).

In general, it can be said that translation is always in direct contact with the epistemological changes of the societies to which it is related. In 
my opinion, this is the most fascinating aspect of translating: its power to disseminate new ways of understanding our contemporary reality beyond stable meaning, thus distrusting the possibility of any meaning that could be fully present in texts and therefore "supposedly recoverable and repeated elsewhere without the interference of the subjects, as well as the cultural, historical, ideological or political circumstances involved" (Arrojo, 1998, p. 25). That is why concepts which are widely used nowadays - such as manipulation, ideology, power, or cultural turn have been incorporated into translation studies in order to enlarge the traditional definitions of translation.

In our hybrid societies, what is needed is a form of legal translation that takes into account the asymmetries of global society. We need a type of translator who has a profound distrust of the possibility that there might be an intrinsically stable meaning present in texts and who, as a result, also believes that it is not possible to recover this exact equivalent meaning in any translation, into any language, at any given time, without some kind of temporal, cultural or political interference. That is why I thoroughly agree with Appiah (1993/2000) when he says:

What I would like to do in this essay is to explore some of the reasons why it is that this prima facie thought should be resisted. I shall argue that most of what interests us in the translations that interest us most is not meaning, in the sense that philosophy of language uses the term: in many cases ... getting the meaning, in this sense, right is hardly even a first step towards understanding. (p. 418)

Meaning, then, "is an effect of language, not a prior presence merely expressed in language. It therefore cannot be simply extracted from language and transferred" (Davis, 2001, p. 14). Meaning cannot be safely or cleanly transferred from one linguistic system to another (Davis, 2001, p. 18). From this perspective, it is impossible to achieve a perfect translation, not because "there is a definite set of desiderata and we know they cannot all be met; it is rather that there is no definite set of desiderata ... we should give up language that implies an epistemology in which the work has already a meaning that is waiting for us to find" (Appiah, 1993/2000, pp. 425-426).

\subsection{Towards a new model}

In this new translation model, we start from the premise that translating is representing in the Foucaultian (1966) sense of the concept: representations are fictitious contradictory constructions originated by social relationships and different forms of subjectivity. The new model understands that identities are tied to representations of cultures and that 
the discursive codes we use are only historically constructed arbitrary orders, which are fixed and unchangeable in appearance but are biased by concrete ideologies. Through these orders we understand the world, because reality does not exist beyond representation. In this line of thought, taking Roland Barthes' (1957, 1970/2005, 1972) “referential illusion" and the breakdown of mimetic theory (Foucault 1966, pp. 13-15) into account, I suggest that making a translation is making a representation of reality that is never neutral; it is re-presenting, from a concrete point of view, the original text. Understood in this way, the new way of translating will give voice not only to the original text but also to the ideology of the person who is translating it. It will give voice to any difference that could be related to cultural, ideological or subjective circumstances, beyond any homogeneous, ideally universal law (Arrojo, 1998, pp. 30, 41). Thus, legal language is not a transparent vehicle of reality and any interpretation and translation of this reality can never be neutral or universal (Berk-Seligson, 1990/2002; Cain \& Harrington, 1994; Campos, Schlag, \& Smith, 1996; Colin \& Morris, 1996; Davies, 1996; Minda, 1995; Patterson, 1996).

I also believe that in this new model the fact that global society has gone beyond monolingualism should be taken into account: "There are no mother tongues, just linguistic sites one takes her/his starting point from" (Braidotti, 1994, p. 13). This is the case because all languages need others, because even although they do speak the same language, human beings are continually translating, inhabiting the other's language. This, in fact, is the only one we speak, often with monolingual determination, in an attempt to make it distant, deserted and uninhabitable. It is an other's language that we will feel, explore and reinvent not with a route or map but rhizomatically (Deleuze \& Guattari, 1980, pp. 18-22; Derrida, 1997/2000, p. 38). A language is always many languages: "there are, in one linguistic system, perhaps several languages or tongues ... There is impurity in every language" (Derrida, 1982/1985, p. 100). That is why we must not forget that translation:

$\ldots$ is no longer simply a linguistic operation that consists in transporting meaning from one language to another ... it is an operation of thought through which we must translate ourselves into the thought of the other language, the forgotten thinking of the other language. We must translate ourselves into it and not make it come into our language. It is necessary to go toward the unthought thinking of the other language. (Derrida, 1982/1985, p. 115)

Used like this, language is a way of crossing frontiers, because it reflects the transnational nature of the legal world:

Babelization does not therefore wait for the multiplicity of languages. The identity of a language can only affirm itself as identity to itself by opening itself to the hospitality of a difference 
from itself or of a difference with itself ... The crossing of borders always announces itself according to the movement of a certain step [pas] - and of the step that crosses a line. An indivisible line. And one always assumes the institution of such an indivisibility. Customs, police, visa or passport, passenger identification - all of that is established upon this institution of the indivisible ... Consequently, where the identity or indivisibility of a line is compromised, the identity to oneself and therefore the possible identification of an intangible edge - the crossing of the line becomes a problem. There is a problem as soon as the edge-line is threatened. And it is threatened from its first tracing. (Derrida, 1993/2006, pp. 10-11)

Making language a reflection of this border situation means that whoever uses it de-territorialises words, words which are not calques but rhizomes (Deleuze \& Guattari, 1980). Perhaps more than any other translator, the new translator of legal texts must not forget (consider, for example, all the cases discussed by Berk-Seligson, 1990/2002) that this language is made up, deliberately, of strata, arenas, territorialities, escape routes and de-territorialising and destratifying movements that transform language into a witness of previous traces and scars.

Koskinen (2000b), for instance, demonstrates that in the international field the translation of legal documents is often the result of a political imposition which aims to maintain the illusory appearance of equality between languages. Discourse is a product of specific interests or strategies. Language may construct an interested reality, even when various stories coincide among people who witness the same events. We are all familiar with examples of witnesses who coincide in accusing someone whose innocence is finally proven, even though, logically, they all try to show that their position in the affair is neutral (Potter, 1996, p. 145). Equally important, Potter goes on to say, is the fact that some witnesses are better than others at relating the facts to literary techniques full of detail which sound much more interesting to listeners. Thus, positioning (what Potter calls "footing") is fundamental to the outcome and the linguistic construction of the facts. In this regard, we must always be aware, not only of what is said, but also of the resources legal language has. This is because, for obvious reasons, language aims to be recognised as a competent descriptor by means of processes designed to provide a quality that tries to construct a description of the facts as though it were independent of the agent which produces it - by means of grammatical resources ("it was discovered that ..." substitutes "I discovered that ..."), obscuring agents to prevent speakers making reference to their responsibility in a particular story, making explicit a vast amount of detail or claiming that many people share the same opinion. For example, Maria Wowk (1984) discusses the confession of a murderer who does not directly accuse the victim of being a prostitute 
(which could have been considered an interested claim) but instead constructs a description inferring this fact.

The field of law is, therefore, a linguistic field, in the sense that it is constructed by and defended with words, which by their nature are very difficult to define. The grounds previously offered by Enlightenment are no longer tenable, because the old foundations (universal reason, neutral meanings, stable subjects) have proved to be ideological constructs "negative utopias", says Michel Foucault (1980). The law is always subject to interpretation.

However, the slippery nature of language can also be its ethical strength, as White points out (1990): “The most profound obligation of each of us in using his or her language is to try to recognize what it leaves out, to point to the silence that surrounds it - to acknowledge the terrible incompleteness of all speech, and thus to leave oneself open to hearing other truths, in other languages" (p. 81). It is in the translation of legal texts that the differences between peoples can be more fully seen and more nearly comprehended: that is why "no sentence can be translated into another language without change ... there is no position outside of culture from which the original can be experienced or described. It is read by one of us, translated by one of us speaking to the rest of us" (White, 1990, p. 252).

The asymmetry legal translators have to face in the global era takes us to movement, transgression, firing lines, resisting stable identities (Martín Ruano, 2012, pp. 45-46) and to understanding that a map is not a territory: "The nomad's identity is a map of where s/he has already been . . . the nomad stands for a movable diversity, the nomad's identity is an inventory of traces" (Derrida, 1993/2006, p. 14). The text is a sponge, and in this regard we must remember, like Derrida, that a sponge not only cleans, but also collects impurities.

The new model of legal translation I propose should always take into account that it is not going to be applied in one space, but in a mixture of spaces, from reflection on what divides and what limits, on who divides and why. It is a type of translation that, as those who have practised it know, experiences hospitality (Derrida, 2000), hostility, and the between on a daily basis (Derrida, 1997/2000, p. 77).

We are in a new world situation that demands new ways of translating, especially in such a sensitive field as legal translation. To achieve a more ethical legal translation it will be necessary to destroy the homogeneous, devour universalism and facilitate a new form of thinking and, subsequently, of translating. Translators should be aware of the responsibilities involved here. Every translation upsets the translator, who never comes out of the process unscathed, because translation is never carried out in symmetrical situations, and because language and translation shape our identities (in the plural).

Legal translators must represent the real and its cracks, their own worlds and those of others, polymorphous visions through uniform signs. 
As legal translators, we must look at language with a critical eye, because it is one of the most dangerous instruments of power available to human beings, given that our character, power and the desire to dominate emanate from signs. From this new perspective, translation can be used to stand up to determined social constructs, to introduce new ideas, and to question the status quo (Gentzler, 2008, p. 3).

Pure denotation is an illusion; that is why linguistic meaning is essentially connotative, that is, intersubjective, pragmatic and adapted to the situation. Any attempt to present it as a univocal, stable instrument that is spectacularly faithful to a reality which aims to appear objective fulfils an ideological function.

\section{Concluding remarks}

Translating is an act of appropriation, a kind of collision which, if not dealt with carefully, may act according to a mould created by the dominating power, which may be of many different types (Bassnett, 2007 , p. 20). Therefore, translating "is not simply an act of faithful reproduction but, rather, a deliberate and conscious act of selection, assemblage, structuration, and fabrication - and even, in some cases, of falsification, refusal of information, counterfeiting, and the creation of secret codes. In these ways translators, as much as creative writers and politicians, participate in the powerful acts that create knowledge and shape culture" (Tymoczko \& Gentzler, 2002, p. xxi). Translation in the 21 st century is a permanent condition of the human being which is reflected in a discursive practice revealing the multiple signs of polyvalence with which cultures are constructed (Gentzler, 2008).

The studies mentioned above, and many others, in the field of both translation and Critical Legal Studies, in our global, hybrid, asymmetrical society, have convinced many scholars that the ethical codes of the legal studies referred to above do not guarantee the achievement of unmediated communication, illusory as that is. Our aim as translators of legal texts is to closely examine why one particular order is imposed on us (and not another) as being natural, universal and transparent, despite its undoubtedly belonging to one particular world and not others; to deconstruct the limits of concepts of justice, the law and right, of values, norms, prescriptions that have been imposed and sedimented there, from then on remaining more or less readable or presupposed, argues Derrida (apud Davis, 2001, p. 95). Translation theorists are now deconstructing "the relationship of the translator to the source and target cultures, and even ... what constitutes a culture and a translation" (Davis, 2001, p. 96). No text type can expect to be interpreted univocally and universally in such a hybrid society as the present one in which fundamental concepts in one culture do not have exact equivalents in others. 
Given this state of affairs, legal studies and translation studies have evolved alongside each other, recognising the multiple conflicting pressures hanging over the translator, the lawyer, the judge, and all the other agents involved in the process. In these circumstances, a theory of translation should attempt to raise the translators' conscience "as writers concerning the responsibility they will face in the seminal role they will play in the establishment of all sorts of relationships between cultures" (Chesterman \& Arrojo, 2000, p. 159). How can we not reflect on the problems and consequences of hedges and self-corrections, which can be interpreted by the judge as a lack of professionalism on the part of the interpreter, as a sign of interpreter incompetence or lack of security, or even as a sign of a lack of truth on the part of the witness (Berk-Seligson, 1990/2002, pp. 179-183)?

The problem of justice is bound to language because law and judgement "perform in language - in a particular idiom. Application of the law to those who do not understand its idiom would be unjust, or irresponsible, in the sense that it applies a general code that clearly does not respond to a particular case" (Davis, 2001, p. 96). Both in the field of Critical Legal Studies and in the new trends in translation studies there is a deep distrust of universal meaning and, consequently, of the epistemic foundations historically offered by lawyers and linguists - I am referring to foundational concepts such as homogeneous and universal meaning and rights evoked by current debates about a cluster of ideas such as truth, knowledge, meaning, reason and objectivity.

We can no longer naively rely on the foundations once offered by our legal system and by those translation theories that believed in equivalent meaning. Instead, we must perform a deconstruction of "normal" courtroom proceedings, keeping in mind that legal translation is no longer neutral but ideologically charged, since it is nowadays a Lyotardian "differend", a Foucaultian "representation" or a Derridean "hospitality problem".

\section{References}

Appiah, K. A. (1993/2000). Thick translation. In L. Venuti (Ed.), The translation studies reader (pp. 417-429). London: Routledge.

Appiah, K. A. (2006). Cosmopolitanism: Ethics in a world of strangers. London: Penguin.

Arrojo, R. (1994). Deconstruction and the teaching of translation. TextConText, 9, 1--12.

Arrojo, R. (1998). The revision of the traditional gap between theory and practice and the empowerment of translation in postmodern times. The Translator, 4(1), 25-48.

Arrojo, R. (1999). Interpretation as possessive love: Hélène Cixous, Clarice Lispector and the ambivalence of fidelity. In S. Bassnett \& T. Harish (Eds.), Postcolonial translation: Theory and practice (pp. 141-161). London: Routledge. 
Arrojo, R. (2001a). The power of originals and the scandals of translation: A reading of Edgar Allan Poe's "The Oval Portrait". In M. Calzada (Ed.), Translation and ideology (pp. 165-180). Manchester: St. Jerome.

Arrojo, R. (2001b). La reevaluación del papel del traductor en el postestructuralismo: Nietzsche, Borges y la compleja relación entre origen y reproducción. R. Martín \& J. Torres (Translation into Spanish. English original Rethinking the role of the translator in post-structuralism, 2001). In R. Álvarez (Ed.), Cartografías de la traducción (pp. 38-56). Salamanca: Ediciones Colegio de España.

Arrojo, R. (2001-2002). Algunas aventuras textuales de Don Quijote y Pierre Menard: La traducción y lo flagrante de la transferencia. J. Mallo. Debats, 75, 24-35.

Barthes, R. (1957). Mythologies. Paris: Éditions du Seuil.

Barthes, R. (1970/2005). L'Empire des signes. Paris: Éditions du Seuil.

Barthes, R. (1972). Le degree zéro de l'écriture. Paris: Éditions du Seuil.

Bassnett, S. (2007). Culture and translation. In P. Kuhiwczak \& K. Littau (Eds.), A companion to translation studies (pp. 13-23). Clevedon: Multilingual Matters.

Bauman, Z. (1999). Culture as praxis. London: SAGE.

Beaton, M. (2007). Interpreted ideologies in institutional discourse: The case of the European Parliament. The Translator, 13(2), 271-296.

Beaton, M. (2010). Negotiating identities in the European Parliament: The role of simultaneous interpreting. In M. Baker, M. Olohan, \& M. Calzada (Eds.), Text and context: Essays on translation and interpreting in honour of Ian Mason (pp. 117-138). Manchester: St. Jerome.

Beck, U. (2006). The cosmopolitan vision. Cambridge: Polity.

Belsey, C. (1980/1985). Critical practice. London: Routledge.

Benjamin, A. (1989). Translation and the nature of philosophy: A new theory of words. New York: Routledge.

Berk-Seligson, S. (1990/2002). The bilingual courtroom: Court interpreters in the judicial process. Chicago, IL: The University of Chicago Press.

Bielsa, E. (2010). Cosmopolitanism, translation and the experience of the foreign. Across Languages and Cultures, 11(2), 161-174.

Bielsa, E., \& Hughes, C. W. (2009). Globalization, political violence and translation. New York, NY: Palgrave Macmillan.

Braidotti, R. (1994). Nomadic subjects. New York, NY: Columbia University Press.

Brown, C. E. (1995). Riding the waves of fortune: Translating legislation of the successor soviet republics. In M. Morris (Ed.), Translation and the law (pp. 67-83). Amsterdam: John Benjamins.

Cain, M., \& Harrington, C. B. (Eds.). (1994). Lawyers in a postmodern world: Translation and transgression. New York, NY: New York University Press.

Campos. P. F., Schlag, P., \& Smith, S. D. (1996). Against the law. Durham, NC: Duke University Press.

Castells, M. (2009). Communication power. Oxford: Oxford University Press.

Chesterman, A. (1997). Memes of translation: The spread of ideas in translation theory. Amsterdam: Johns Benjamins.

Chesterman A., \& Arrojo, R. (2000). Shared ground in translation studies. Target, 12(1), 151-160. 
Colin, J., \& Morris, R. (1996). Interpreters and the legal process. Winchester: Waterside.

Cooke, M. (1995). Understood by all concerned?: Anglo/Aboriginal legal translation. In M. Morris (Ed.), Translation and the law (pp. 37-63). Amsterdam: John Benjamins.

Cronin, M. (2003). Translation and globalization. London: Routledge.

Davies, M. (1996). Delimiting the law: "Postmodernism" and the politics of law. London: Pluto.

Davis, K. (2001). Deconstruction and translation. Manchester: St. Jerome.

Delanty, G. (2009). The cosmopolitan imagination. Cambridge: Cambridge University Press.

Deleuze, G., \& Guattari, F. (1980). Mille plateaux. Paris: Éditions de Minuit.

Derrida, J. (1972/1982). Différance in Margins of Philosophy. A. Bass (Translation into English. French original Différance, 1972). Chicago, IL: University of Chicago Press.

Derrida, J. (1981). Éperons: Les styles de Nietzsche/Spurs. Nietzsche's Styles. Chicago, IL: University of Chicago Press.

Derrida, J. (1982/1985) The ear of the other: Otobiography, transference, translation. P. Kamuf (Translation into English. French original Oreille d'Lautre, 1982). Lincoln, NE: University of Nebraska Press.

Derrida, J. (1989/1992). Force of law: The mystical foundation of authority. M. Quaintance (Translation into English. French original Force de loi, 1989). In D. Cornell, M. Rosenfeld, \& D. G. Carlson (Eds.), Deconstruction and the possibility of justice (pp. 3-67). London: Routledge.

Derrida, J. (1993/2006). Aporias. T. Dutoit (Translation into English. French original Apories, 1993). Meridian: Crossing Aesthetics.

Derrida, J. (1996/1998). Monolingualism of the other. P. Mensah (Translation into English. French original Monolinguisme de l'autre, 1996). Stanford, CA: Stanford University.

Derrida, J. (1997/2000). Of hospitality. R. Bowlby (Translation into English. French original De l'hospitalité, 1997). Stanford, CA: Stanford University Press.

Derrida, J. (2000). Hospitality. B. Stocker \& F. Morlock (Translation into English. French original Hospititalité, 2000). Angelaki. Journal of the Theoretical Humanities, 5(3), 3-18.

Derrida, J. (2001). Sur la parole. La Tour-d'Aigues: Éditions de l'aube.

Foucault, M. (1966). Les mots et les choses, une archeology des sciences humans. Paris: Gallimard.

Foucault, M. (1980). Power/knowledge: Selected interviews and other writings, 1972 1977. C. Gordon (Translation into English. French original Pouvoir/Savoir, 1977). New York, NY: Pantheon.

Foucault, M. (1970). The order of discourse. In R. Young (Ed.). (1981), Untying the text: A post-structuralist reader (pp. 48-78). Boston, MA: Routledge.

Foucault. M. (1971/1994). The order of things: An archeology of human sciences. New York, NY: Vintage.

Gentzler, E. (2008). Translation and identity in the Americas: New directions in translation theory. London: Routledge. 
Harvey, M. (2002). What's so special about legal translation? Meta - Translators' Journal, 47(2), 177-185.

Heller, A. (1992). Rights, modernity, democracy. In D. Cornell, M. Rosenfeld, \& D. G. Carlson (Eds.), Deconstruction and the possibility of justice (pp. 346-360). London: Routledge.

Hillis Miller, J. (1992). Laying down the law in literature. In D. Cornell, M. Rosenfeld, \& D. G. Carlson (Eds.), Deconstruction and the possibility of justice (pp. 305-329). London: Routledge.

Koskinen, K. (2000a). Beyond ambivalence: Postmodernity and the ethics of translation. Tampere: University of Tampere.

Koskinen, K. (2000b). Institutional illusions: Translating in the EU commission. The Translator, 6(1), 49-65.

Koskinen, K. (2008). Translating institutions: An ethnographic study of EU translation. Manchester: St. Jerome.

Lyotard, J.-F. (1979/1984). The postmodern condition: A report on knowledge, trans. G. Bennington, \& B. Massumi (Translation into English. French original La condition postmoderne, 1979). Minneapolis, MN: University of Minnesota Press.

Lyotard, J.-F., \& Thébaud, J.-L. (1979/1985). Just gaming, trans. W. Godzich, \& J.-L. Thébaud (Translation into English. French original Au juste 1979). Minneapolis, MN: University of Minnesota Press.

Lyotard, J.-F. (1983/1988). The differend: Phrases in dispute. G. Abbeele (Translation into English. French original Le différend, 1983). Minneapolis, MN: University of Minnesota Press.

Martín Ruano, R. (2012). Traducción institucional e indentidad(es): Asimetrías, conflictos, posibilidades. In I. Alonso, J. Baigorri, \& H. Campbell (Eds.), Ensayos sobre traducción jurídica e institucional (pp. 43-68). Granada: Comares.

Mikkelson, H. (2000). Introduction to court interpreting. Manchester: St Jerome.

Minda, G. (1995). Postmodern legal movements: Law and jurisprudence at century's end. New York, NY: New York University Press.

Nóbrega, M. (2010). Presencia del español en las organizaciones internacionales: Las Naciones Unidas. Puntoycoma, 117, 281-309.

Patterson, D. (1996). Law and truth. Oxford: Oxford University Press.

Potter, J. (1996/2008). Representing reality: Discourse, rhetoric and social construction. London: SAGE.

Šarčević, S. (1997). New approach to legal translation. The Hague: Kluwer.

Šarčević, S. (2010). Legal translation in multilingual settings. In I. Alonso, J. Baigorri, \& H. Campbell (Eds.), Translating justice (pp. 19-45). Granada: Comares.

Strandvik, I. (2002). Transparencia, gobernanza y traducción: ¿Ha llegado la hora de un enfoque funcional? In El español, lengua de traducción. Actas del I congreso internacional (pp. 512-521). Madrid: Esletra.

Tosi, A. (2003). European affairs: The writer, the translator and the reader. In A. Tosi (Ed.), Crossing barriers and bridging cultures: The challenges of multilingual 
translation for the European Union (pp. 57-72). Clevedon: Multilingual Matters.

Tymoczko, M., \& Gentzler, E. (Eds.) (2002). Translation and power. Amherst, MA: University of Massachusetts Press.

Vidal, M. C. A., \& Martín, R. (2003). Deconstructing the discourse on legal translation. In L. Pérez González (Ed.), Speaking in tongues: Language across contexts and users (pp. 141-160). Valencia: PUV.

White, J. B. (1990). Justice as translation: An essay in cultural and legal criticism. Chicago, IL: University of Chicago Press.

Wowk, M. (1984). Blame allocation: Sex and gender in a murder interrogation. Women's Studies International Forum, 7, 75-82.

1 This paper is part of the research carried out in the project financed by the Ministerio de Economía y Competitividad FFI2012-35000 Traducción, medios de comunicación y opinión pública. 